\title{
The dependence of tree pollen production on the weather conditions in the south of West Siberia
}

\author{
Ekaterina Lukanina ${ }^{1}$, Tatiana Blyakharchuk²
}

${ }^{1}$ Biological Institute, Tomsk State University (TSU). Tomsk, 36, Lenina Avenue (eloukanina@mail.ru); ${ }^{2}$ Institute of Monitoring of Climatic and Ecological Systems of the Siberian Branch of the RAS (IMCES SB RAS).

Tomsk, 10/3, Academichesky ave. (tarun5@rambler.ru).

Received: 22 April 2017/Accepted: 02 June 2017

\begin{abstract}
In the present study, we have investigated the dependence of the composition of the modern spore and pollen spectra on the composition of the vegetation cover in the southern part of Western Siberia (south of the Tomsk region) using the Tauber traps. We also found out the correlation between the spore and pollen spectra and the weather conditions of the year under study.
\end{abstract}

Keywords: spore and pollen spectra, Tauber traps, climate monitoring.

\section{Introduction}

It is necessary to collect and analyze modern pollen and spores for monitoring purposes. It allows to track the changes in pollen production of vegetation, the dynamics of its species composition in a certain territory. The data of spore and pollen monitoring allows tracking the trends in changing of the modern climate, helping in the reconstruction of the past climate. They are used in allergology and melissospalynology, show anthropogenic impact on the environment. (Dzyuba et al. 2013; Frenguelli et al. 1991; Nenasheva et al. 2011; Ereschenko \& Khlebova 2012; Furnessa 1994).

The purpose of this work was to study the dependence of the composition of the modern spore and pollen spectra on the composition of the vegetation cover and weather conditions in the southern part of Western Siberia for monitoring of the climatic changes and the reconstruction of the palaeoclimate.

\section{Study area}

The pollen was collected with two Tauber traps (Tauber 1974) in the south of the Tomsk region, in the Tom-Yai interfluves (41 kilometers of the railway). The first Tauber trap was located in the steam valley on the northwestern slope in the section of the dark coniferous taiga ( $\mathrm{N} 56^{\circ}$ 19'20.70" E 85'25'30.30"; $202 \mathrm{~m}$ above sea level.). The second one was installed in the fir forest near the railway (N 56 19'07.99" E 85²6'14.01"; $212 \mathrm{~m}$ above sea level) $1 \mathrm{~km}$ to the east from the first trap.

\section{Methods}

The material from the traps has been collected for three years: after the end of vegetation in 2013, 2014 and 2015. After the collection the material was processed the way to isolate only small organic particles (pollen and spores) (Stockmarr 1971). 2 tablets of Lycopodium spores with a known amount of spores were added to the isolated pol- 


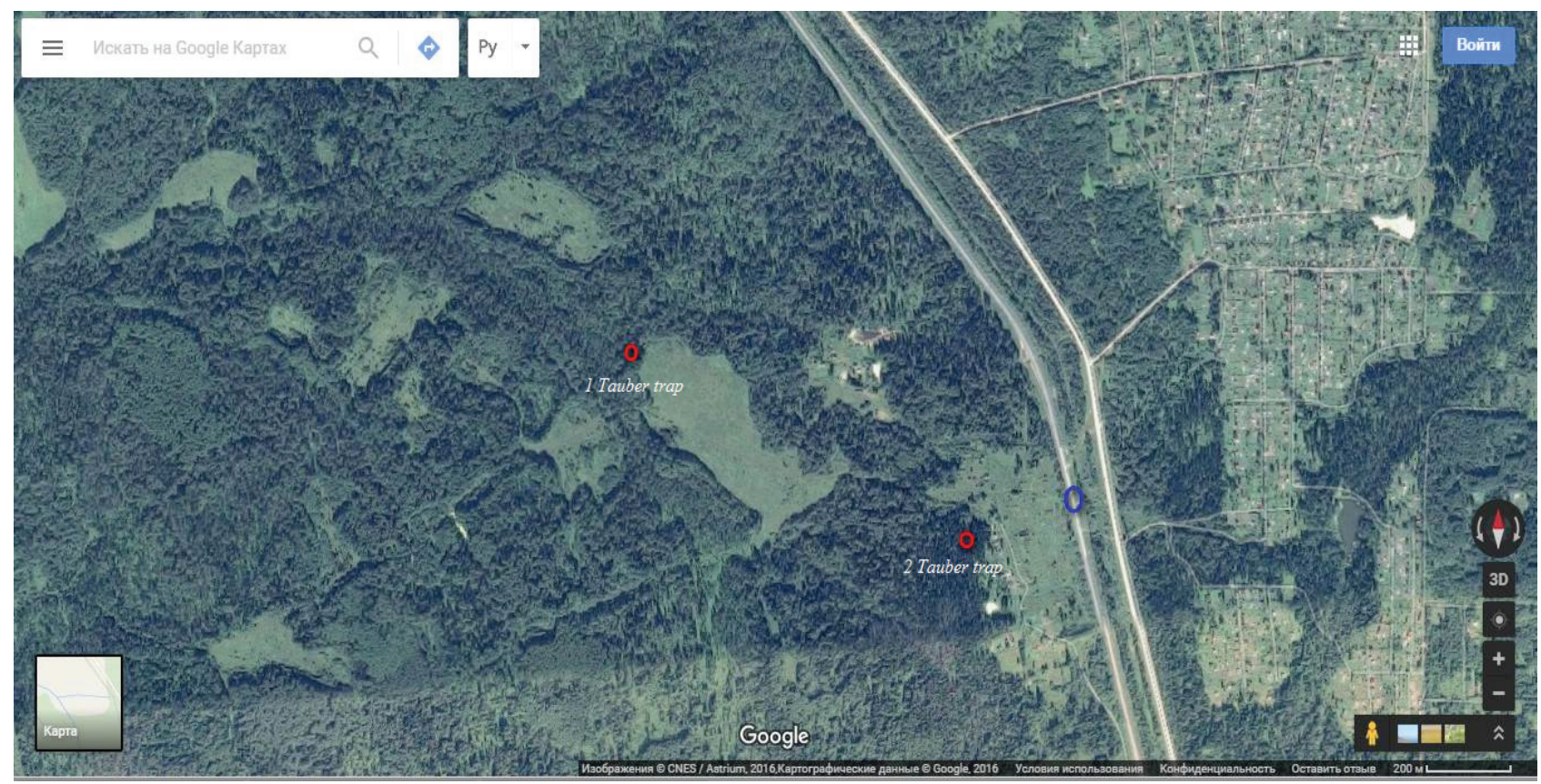

Figure 1. The south of the Tomsk region, 41 kilometers of the railway (Google Maps). Blue color marks the railway station "41 km". Red colour - the places of the installation of the Tauber traps.

len, in order to calculate the pollen productivity index of the vegetation cover.

There was made a geobotanical description of the local phytocoenoses around the traps on the area of $100 \mathrm{~m}^{2}$. The regional vegetation, which pollen could also be transferred to the collection sites, was also considered. The data was obtained on the climate of the south of the Tomsk region and on the weather of the winter and the summer periods for the years studied (the source of the data: Погода и Климат [http://www.pogodaiklimat.ru]).

\section{Results and discussion}

There were big amounts of the pollen of Betula pendula Roth., Abies sibirica Ledeb. and Pinus sylvestris L. in the spectrum of the Tauber trap № 1 for 2013 (Tab. 1, Fig. 2). There was the pollen of Cedar pine (Pinus sibirica Du
Tour) and Siberian spruce (Picea obovata Ledeb.). There were only B. pendula, $P$. sibirica, $A$. sibirica and $P$. obovata of the tree species in the local phytocenosis. The pollen of $P$. sylvestris, B. pendula and Larix $s p$. was brought from the neighboring phytocenoses. There were representatives of the local phytocenosis among the pollen of bushes and herbaceous plants, - Carex sp., Poaceae, Urtica dioica L., Anemone sp. The finds of the Sphagnum spore, as well as the pollen of the representatives of the high-grass association of the forest fringe reflect the regional vegetation Heracleum dissectum Ledeb. and the other species of Apiaceae, Sorbus sibirica Hedl., Anemone, Urtica, Poaceae. Some pollen grains may have been brought from the cultivated areas (Cannabis sativa L., Hordeum sp., Padus avium Mill. and some species of Spiraea.

Table 1. The data on the absolute number of pollen grains and spores of various plant species from the two Tauber traps (№ 1 and № 2) in 2013, 2014 and 2015.

\begin{tabular}{|c|c|c|c|c|c|c|}
\hline Species & 2013, №1 & 2013, №2 & 2014, №1 & 2014, №2 & 2015, №1 & 2015, №2 \\
\hline Abies sibirica & 58 & 173 & 14 & 34 & 12 & 52 \\
\hline Betula pubescens & 7 & 7 & 5 & 3 & 12 & 1 \\
\hline
\end{tabular}




\begin{tabular}{|c|c|c|c|c|c|c|}
\hline Species & 2013, №1 & 2013, №2 & 2014, №1 & 2014, №2 & 2015, №1 & 2015, №2 \\
\hline Betula pendula & 245 & 245 & 250 & 179 & 391 & 207 \\
\hline Larix sp. & 3 & 0 & 0 & 0 & 1 & 0 \\
\hline Picea obovata & 25 & 33 & 6 & 2 & 1 & 5 \\
\hline Pinus sibirica & 24 & 24 & 9 & 24 & 29 & 56 \\
\hline Pinus sylvestris & 74 & 82 & 22 & 35 & 14 & 31 \\
\hline Padus avium & 2 & 5 & 0 & 0 & 0 & 0 \\
\hline Salix sp. & 2 & 1 & 0 & 0 & 0 & 0 \\
\hline Sambucus sibirica & 0 & 3 & 2 & 6 & 4 & 4 \\
\hline Sorbus sibirica & 1 & 0 & 0 & 0 & 0 & 0 \\
\hline Spiraea sp. & 9 & 4 & 17 & 21 & 6 & 14 \\
\hline Aegopodium podagraria & 0 & 2 & 9 & 27 & 0 & 0 \\
\hline Alnaster sp. & 0 & 0 & 0 & 1 & 0 & 0 \\
\hline Anemone sp. & 0 & 0 & 6 & 17 & 14 & 5 \\
\hline Angelica $s p$. & 1 & 0 & 0 & 0 & 0 & 0 \\
\hline Apiaceae & 2 & 1 & 12 & 162 & 4 & 11 \\
\hline Artemisia sp. & 18 & 16 & 9 & 17 & 8 & 11 \\
\hline Asteraceae (Aster-type) & 0 & 0 & 1 & 1 & 0 & 30 \\
\hline Brassicaceae & 0 & 0 & 0 & 0 & 0 & 14 \\
\hline Bupleurum sp. & 0 & 0 & 2 & 0 & 0 & 7 \\
\hline Campanula sp. & 1 & 0 & 0 & 0 & 0 & 0 \\
\hline Cannabis sativa $L$. & 2 & 9 & 8 & 22 & 1 & 1 \\
\hline Carex $s p$. & 9 & 5 & 23 & 11 & 0 & 0 \\
\hline Caryophyllaceae & 0 & 2 & 0 & 1 & 0 & 0 \\
\hline Cerealia sp. & 9 & 0 & 0 & 0 & 0 & 0 \\
\hline Chenopodiaceae & 0 & 0 & 3 & 1 & 3 & 1 \\
\hline Cichorioideae-type & 0 & 1 & 1 & 0 & 0 & 0 \\
\hline Cirsium sp. & 0 & 1 & 0 & 0 & 0 & 0 \\
\hline Corydalis sp. & 0 & 0 & 0 & 9 & 0 & 3 \\
\hline Delphinium sp. & 0 & 5 & 0 & 0 & 0 & 0 \\
\hline
\end{tabular}




\begin{tabular}{|c|c|c|c|c|c|c|}
\hline Species & 2013, №1 & 2013, №2 & 2014, №1 & 2014, №2 & 2015, №1 & 2015, №2 \\
\hline Fabaceae & 0 & 0 & 0 & 7 & 0 & 0 \\
\hline Filipendula sp. & 0 & 14 & 2 & 0 & 0 & 0 \\
\hline Galium sp. & 0 & 0 & 0 & 1 & 1 & 0 \\
\hline Gentiana sp. & 0 & 1 & 0 & 0 & 0 & 0 \\
\hline Heracleum sp. & 1 & 5 & 2 & 90 & 0 & 0 \\
\hline Hordeum sp. & 14 & 5 & 0 & 0 & 0 & 0 \\
\hline Hypericum sp. & 1 & 4 & 2 & 0 & 0 & 0 \\
\hline Origanum sp. & 0 & 0 & 0 & 2 & 0 & 0 \\
\hline Pedicularis sp. & 0 & 0 & 0 & 1 & 0 & 1 \\
\hline Plantago sp. & 0 & 1 & 0 & 23 & 0 & 0 \\
\hline Poaceae & 25 & 33 & 35 & 46 & 5 & 15 \\
\hline Polygonum sp. & 0 & 2 & 0 & 0 & 0 & 0 \\
\hline Primula sp. & 0 & 1 & 0 & 0 & 0 & 0 \\
\hline Ranunculaceae & 0 & 0 & 4 & 1 & 0 & 0 \\
\hline Ranunculus sp. & 0 & 3 & 0 & 0 & 0 & 0 \\
\hline Rosaceae & 1 & 0 & 1 & 0 & 2 & 3 \\
\hline Senecio $s p$ & 0 & 1 & 0 & 0 & 0 & 0 \\
\hline Thalictrum sp. & 0 & 2 & 3 & 4 & 0 & 0 \\
\hline Triticum sp. & 0 & 0 & 1 & 0 & 0 & 0 \\
\hline Trollius asiaticus & 1 & 3 & 0 & 1 & 0 & 0 \\
\hline Urtica sp. & 1 & 1 & 12 & 57 & 34 & 24 \\
\hline Equisetum $s p$ & 1 & 1 & 3 & 0 & 0 & 0 \\
\hline Matteuccia struthiopteris & 0 & 2 & 0 & 0 & 0 & 0 \\
\hline Monolete & 0 & 1 & 0 & 2 & 0 & 4 \\
\hline Sphagnum & 1 & 0 & 1 & 0 & 0 & 0 \\
\hline Lycopodium (added) & 168 & 168 & 241 & 174 & 19 & 19 \\
\hline
\end{tabular}

The pollen of wood species is highlighted in yellow, the blue color marks shrubs, the green one - herbaceous plants, pink - spores. The plants of the local phytocenosis are underlined. 


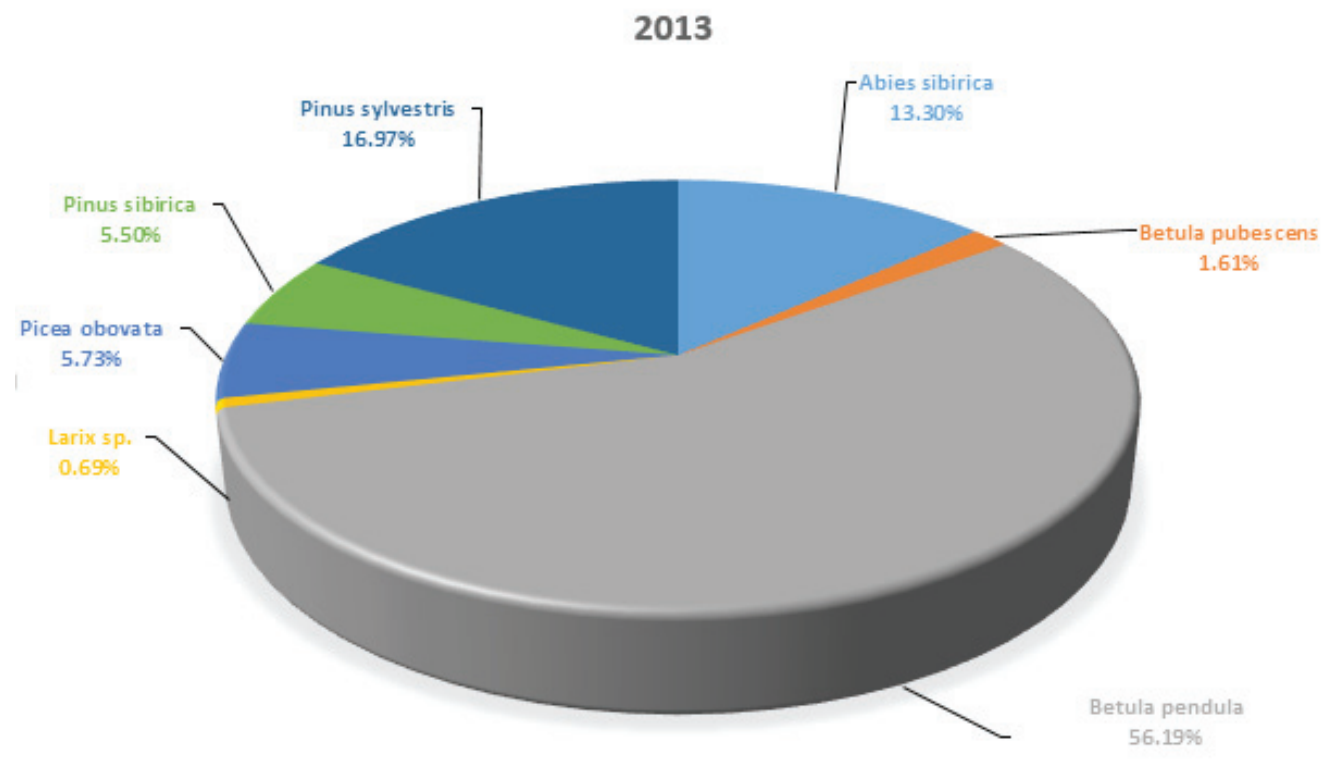

Figure 2. The percentage of the pollen of tree species from the sample of the Tauber trap №1, 2013

In 2014 the pollen productivity of the coniferous species decreased compared to the previous year according to the data from the trap № 1 (Tab. 1). The amount of B. pendula pollen slightly increased. There is Betula pubescens Ehrh. and $P$. sylvestris pollen in the sample. The tree species were not found in the local phytocenosis. The new species appear among the non-wood pollen in spectrum. There was Sambucus sibirica Nakai among them, which did not participate in the local phytocenosis. The increase in the number of the pollen of Apiaceae, the appearance of Asteraceae can be also noted. Triticum sp. had an anthropogenic origin.

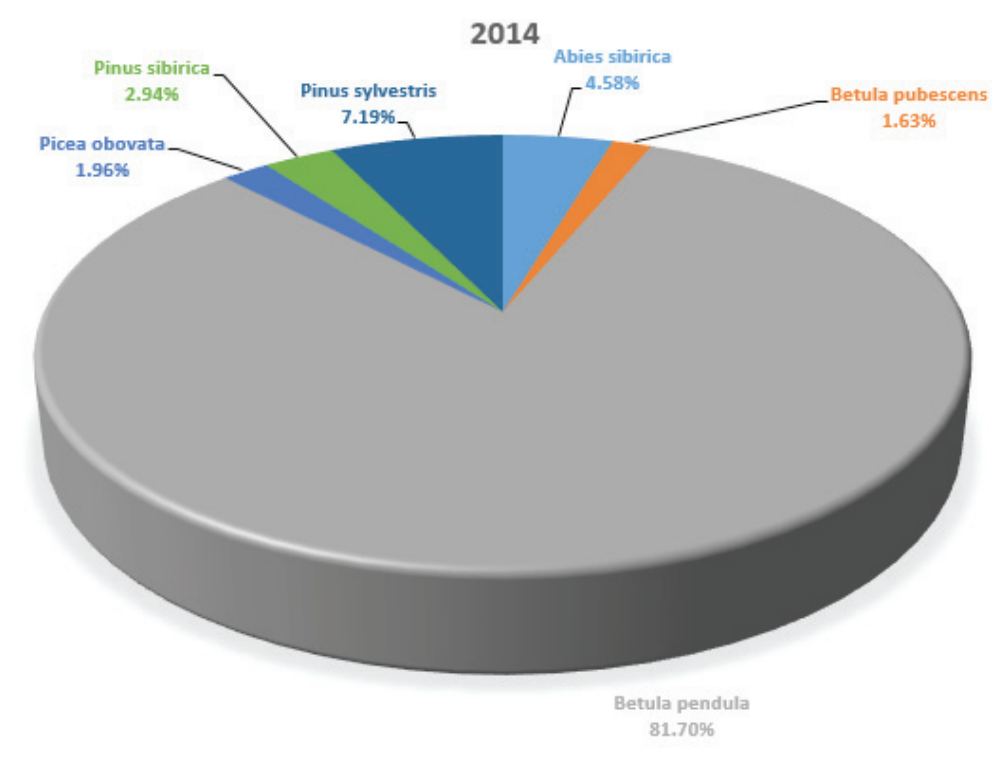

Figure 3. The percentage of the pollen of tree species from the sample of the Tauber trap №1, 2014

In 2015 the amount of Betula pendula pollen increased sharply in the trap № 1. The pollen production of Pinus sibirica rose compared to the previous years' results. The quantity of the pollen grains of Abies, Picea and Pinus sylvestris has decreased. Larix pollen was met again. There are fewer species represented in the spectrum. It is because of the big increase of the tree pollen in the trap compared to the previous years. So fewer remaining plant species were examined. 


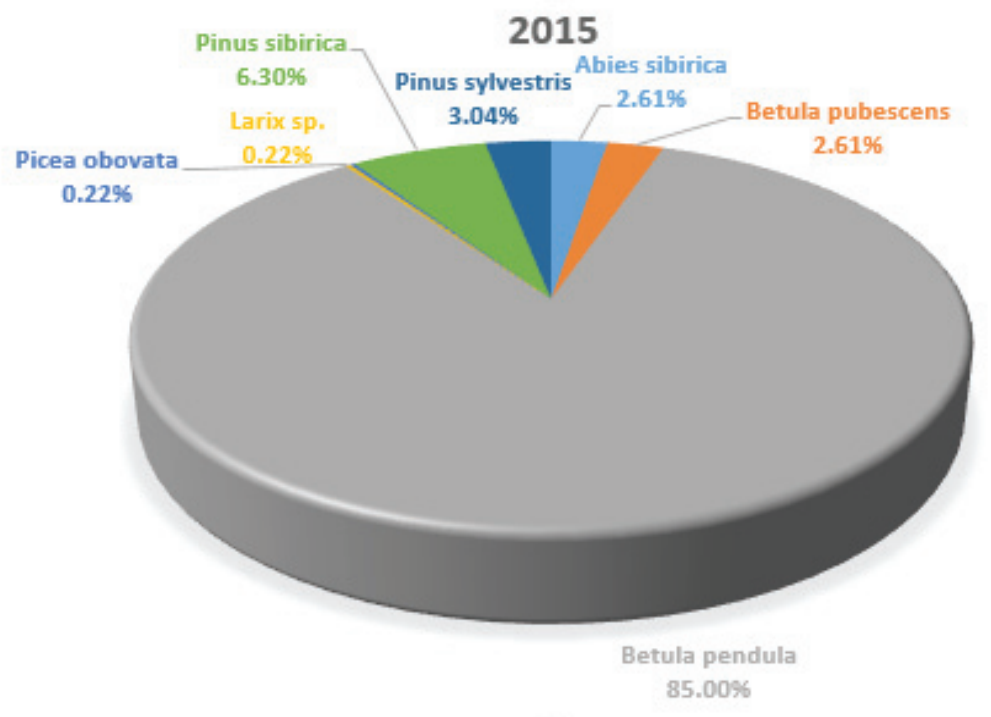

Figure 4. The percentage of the pollen of tree species from the sample of the Tauber trap №1, 2015.

The second Tauber trap was located in a section of dark coniferous fir forest with a green shallow-grass cover, not far from the garden plots (Fig. 1). The spore-pollen spectra contained more species in the samples of the Tauber trap № 2, than of the trap № 1 (Tab. 1). In 2013, the amount of Betula pendula pollen was the biggest. There was a lot of pollen of Abies, which was predominant in the local phytocenosis. The productivity of the rest tree species was quite high, in spite of the fact that only one Picea tree and two trees of Pinus sibirica undergrowth were present in the local phytocenosis. The number of spores in the spectrum of the second trap increased as well as the pollen content of Ranunculaceae, Poaceae and Rosaceae. The spores of the fern Matteuccia struthiopteris (L.) appeared.

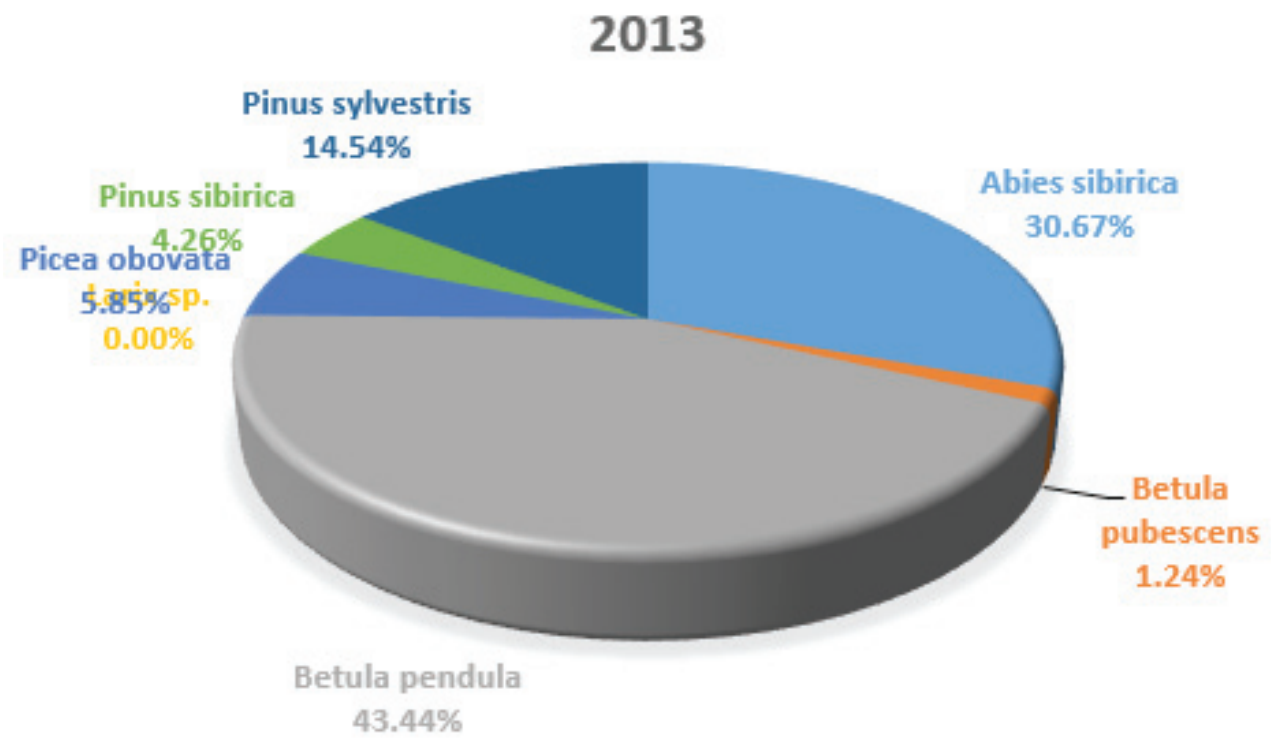

Figure 5. The percentage of the pollen of tree species from the sample of the Tauber trap №2, 2013

In 2014 the pollen productivity of Abies has decreased about twice compared to 2013. The amount of Picea pollen has become about six times lower. The pollen production of Betula pendula and Pinus sylvestris was also decreased. The contribution of the pollen of Sambucus and Spiraea increased among the shrubs. The pollen production of Apiaceae increased more than 100 times in absolute pollen count for the herbaceous plants. Perhaps it was due to the drift of the Apiaceae pollen trapped by the insects or small rodents. The abundance of the remains of small fauna was noted in this trap. 


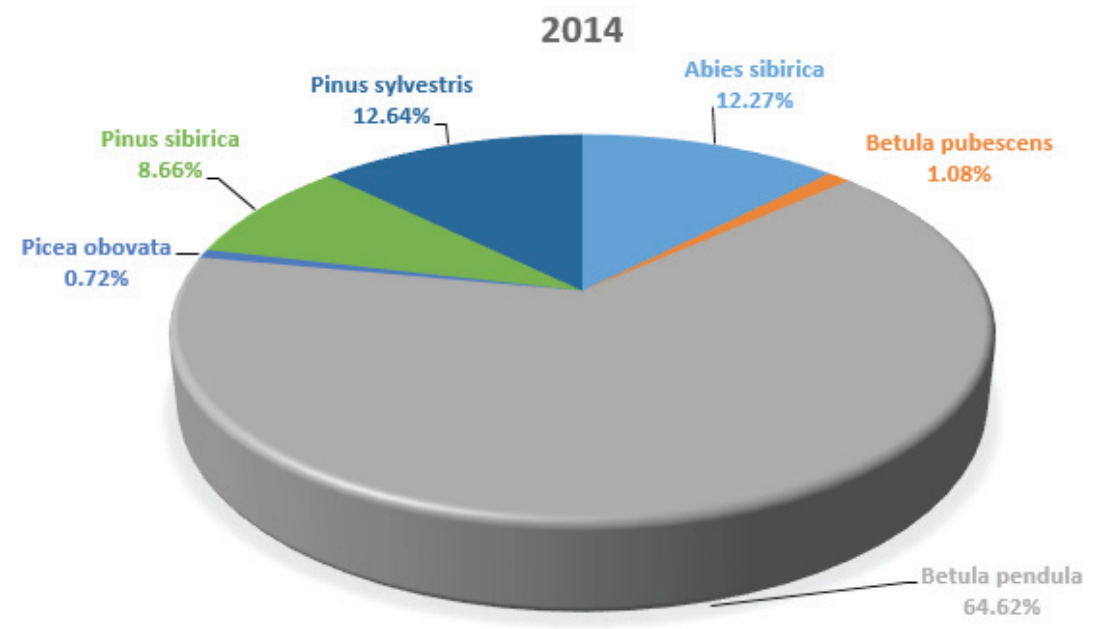

Figure 6. The percentage of the pollen of wood species from the sample of the Tauber trap №2, 2014

In 2015, the productivity of all the tree species increased dramatically in both the first and the second traps. Betula pendula again dominated. There was quite a lot of Abies and Pinus sibirica. There was a lot of pollen of Asteraceae, as well as Brassicaceae among the herbaceous plants. It indicates the increase of the anthropogenic influence on this territory.

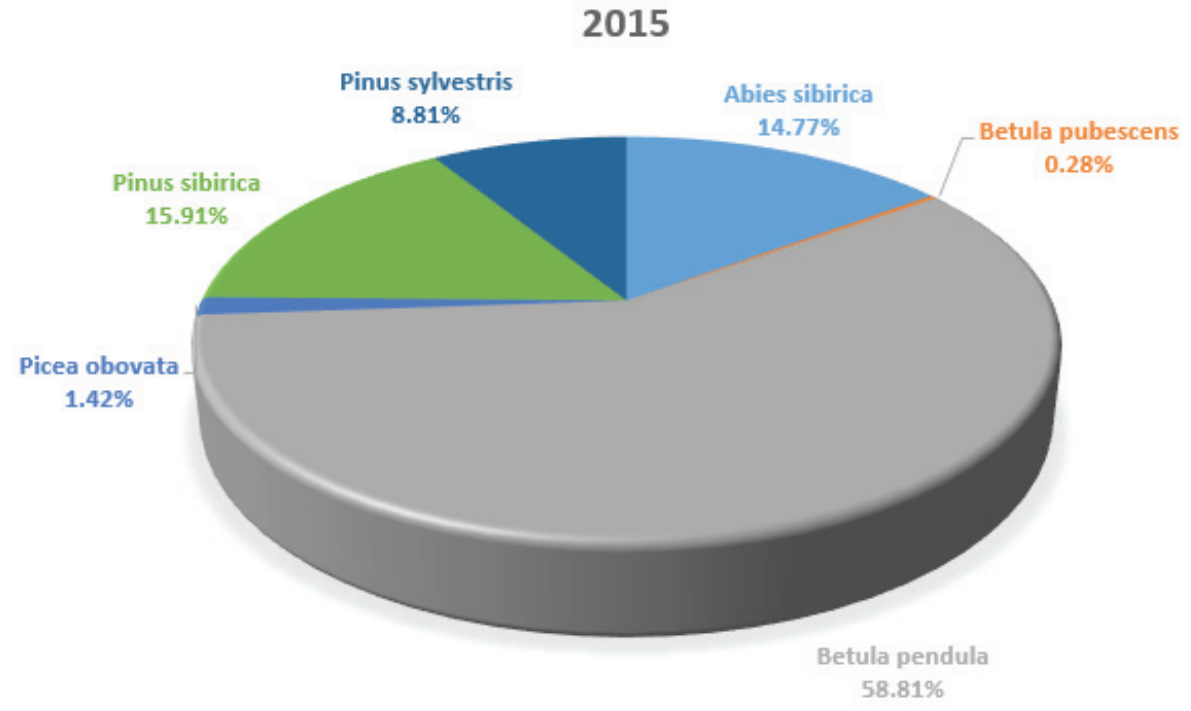

Figure 7. The percentage of the pollen of wood species from the sample of the Tauber trap №2, 2015

The pollen productivity of the phytocenosis at the locations of the traps was calculated with the added spores of $L y$ copodium, assuming that the amount of Lycopodium spores counted in the spore-pollen spectrum simultaneously with the rest of the pollen and spores is inversely proportional to the pollen productivity of the vegetation. The relationship between the pollen productivity of vegetation and the weather conditions of the corresponding year is shown in the graphs below (Figs. 8-11). Thus it has been revealed that the pollen productivity of phytocenoses increases significantly with the increase of the preceding winter temperatures and an increase in the amount of winter precipitation relative to the norm. 


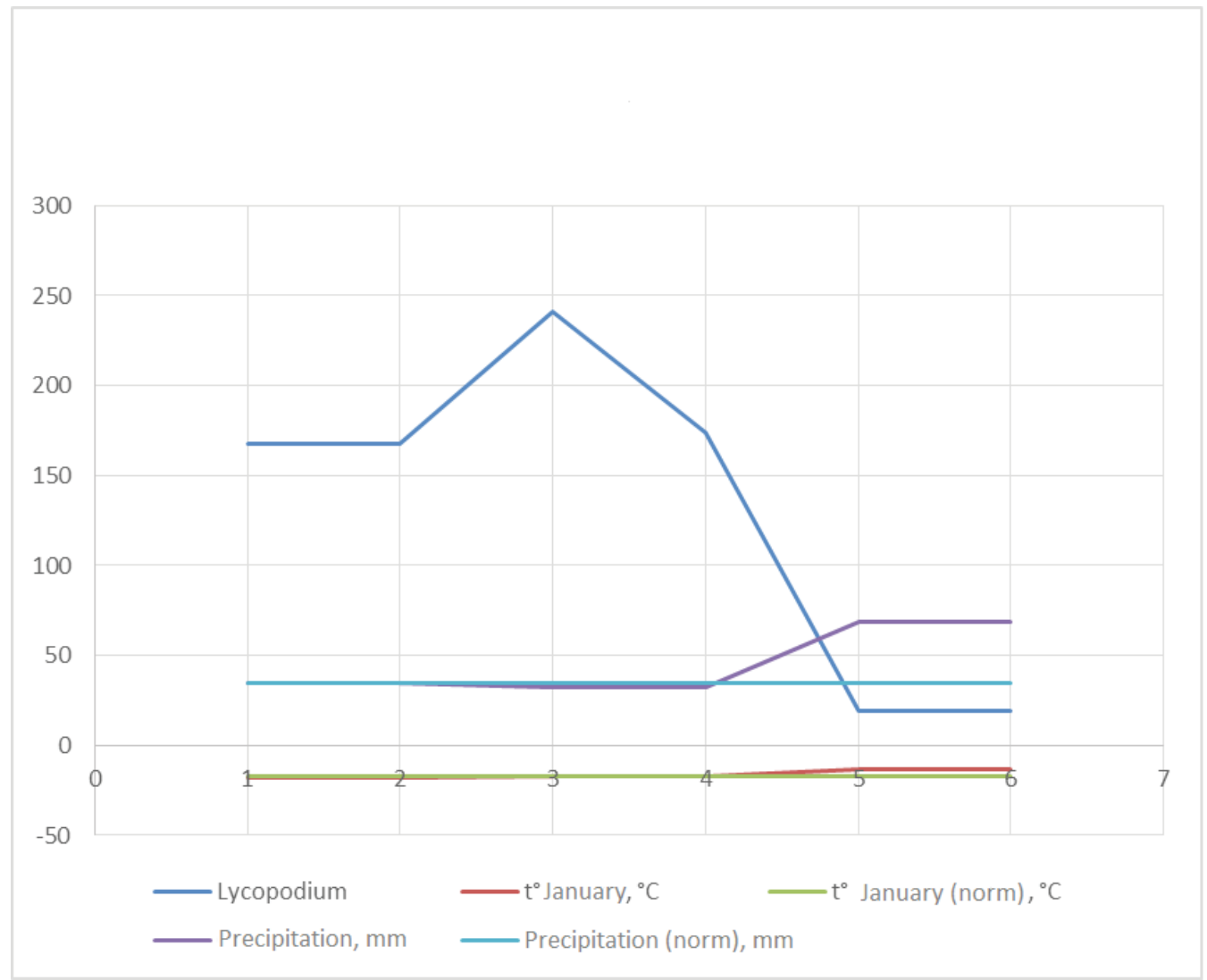

Figure 8. The relation of the absolute number of Lycopodium spores and weather and climate conditions in January 2013, $2014,2015$. 1.Trap №1, 2013 2. Trap №2, 2013 3. Trap №1, 2014 4. Trap №3, 2014 5. Trap №1, 2015 6. Trap №2, 2015.

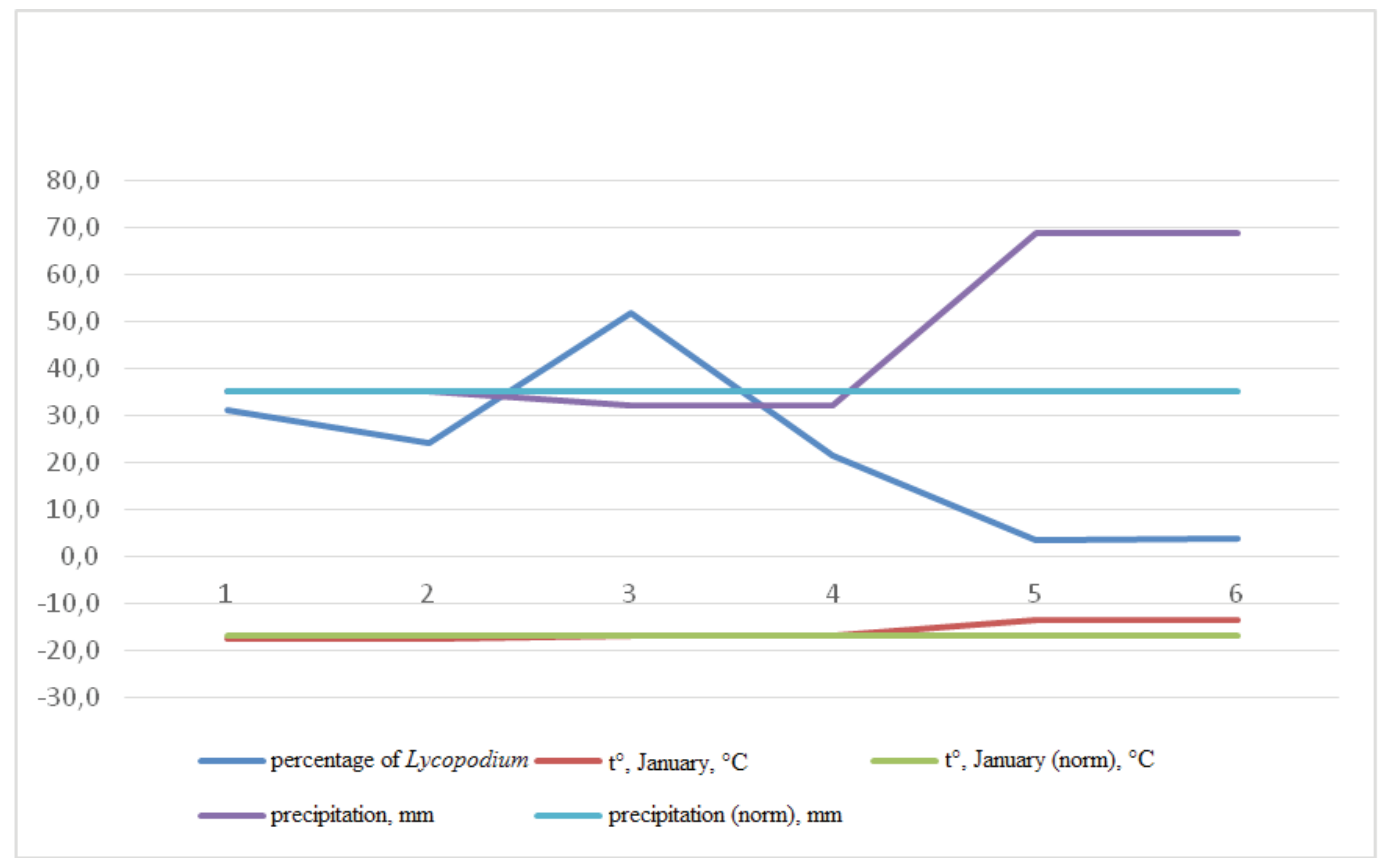

Figure 9. The relation of the percentage of Lycopodium spores and weather and climate conditions in January 2013, 2014, 2015. 1.Trap №1, 2013 2. Trap №2, 2013 3. Trap №1, 2014 4. Trap №3, 2014 5. Trap №1, 2015 6. Trap №2, 2015. 


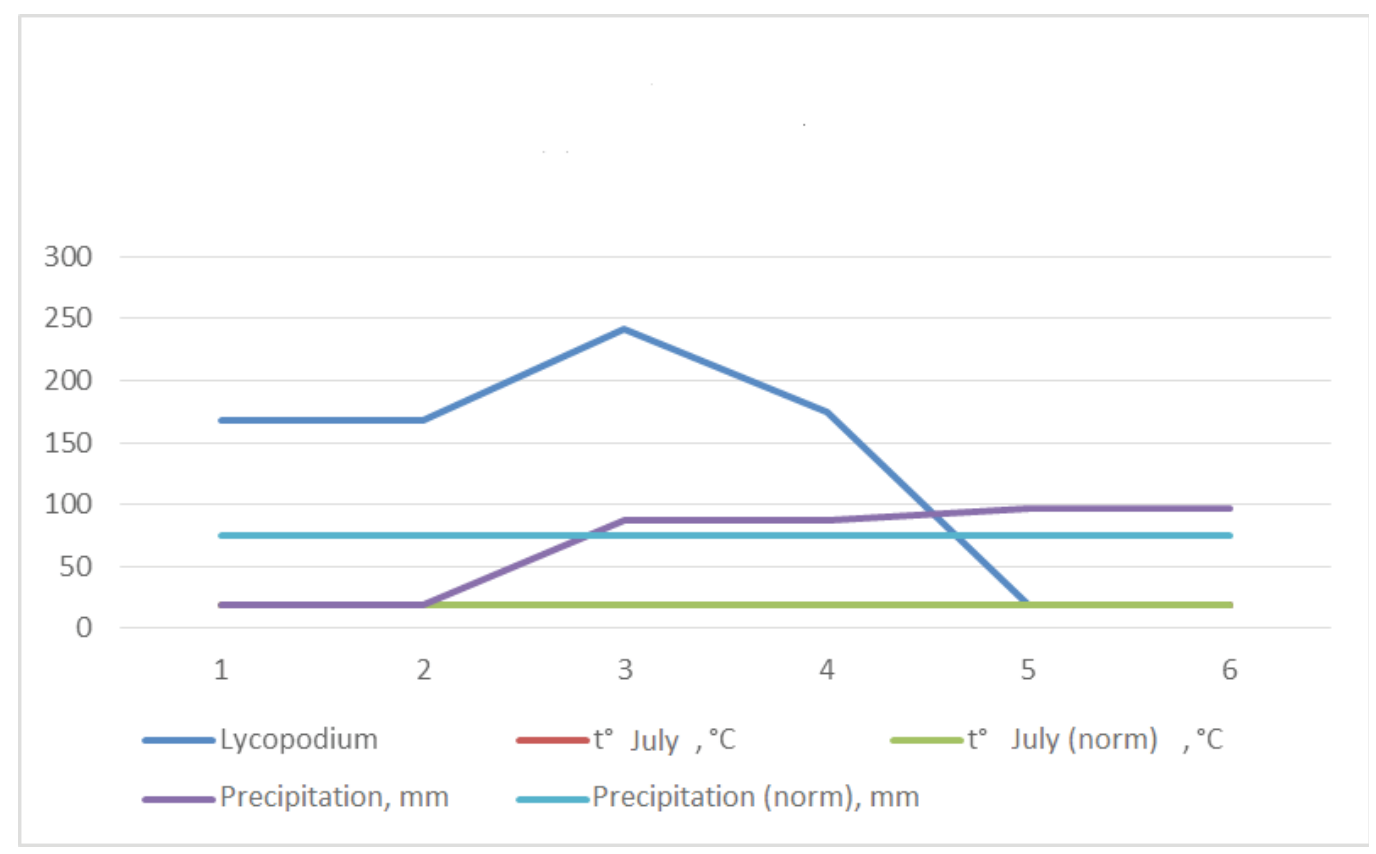

Figure 10. The ratio of the absolute number of Lycopodium spores and weather and climate conditions in July 2013, $2014,2015$. 1.Trap №1, 2013 2. Trap №2, 2013 3. Trap №1, 2014 4. Trap №3, 2014 5. Trap №1, 2015 6. Trap №2, 2015.

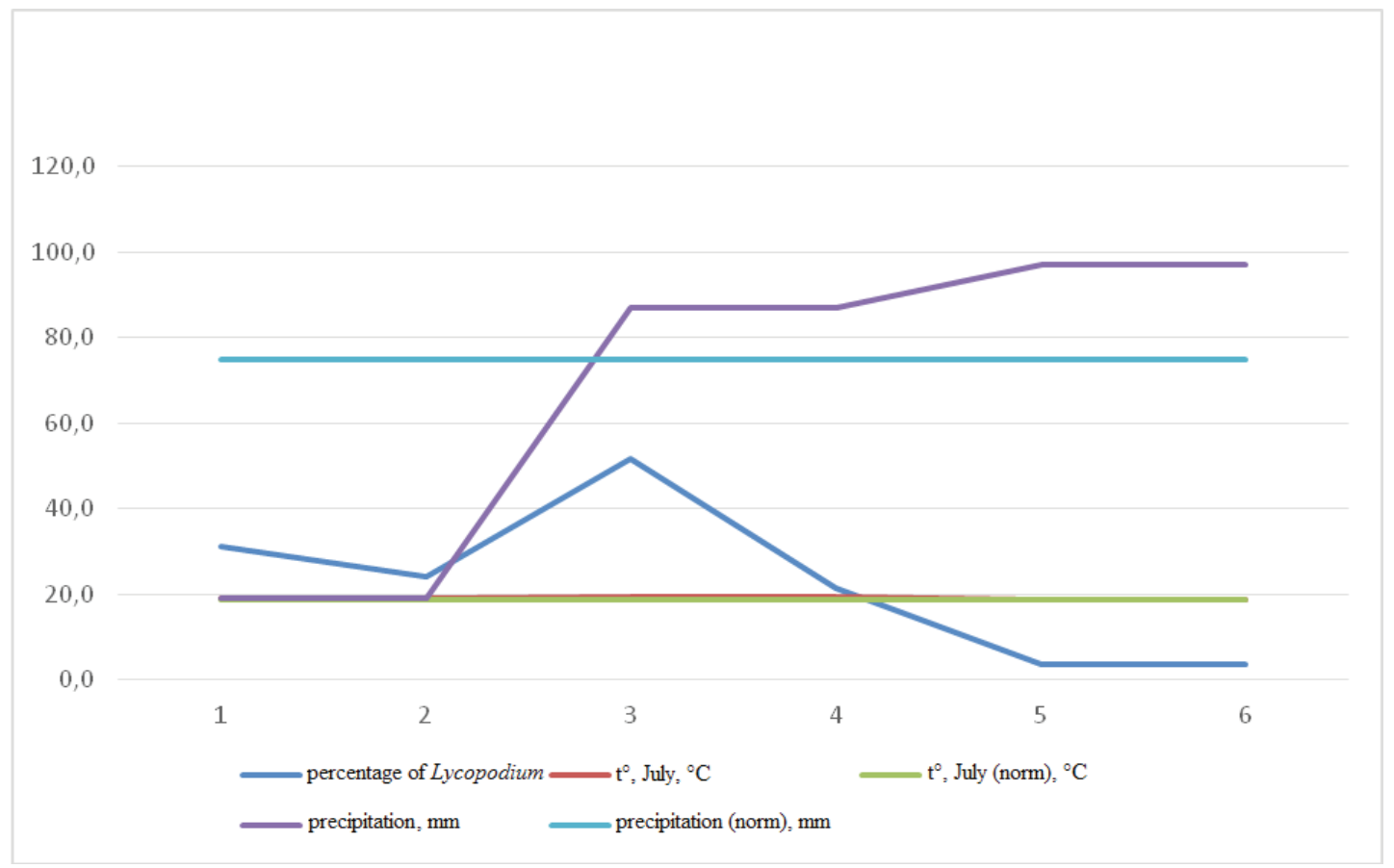

Figure 11. The ratio of the percentage of Lycopodium spores and weather and climate conditions in July 2013, 2014, 2015. 1.Trap №1, 2013 2. Trap №2, 2013 3. Trap №1, 2014 4. Trap №3, 2014 5. Trap №1, 2015 6. Trap №2, 2015. 
The effect of the changes of the summer weather conditions is different. The pollen productivity is relatively small with the decrease in precipitation below normal and the increase in average daily temperatures above the norm. In 2014, the lowest productivity is observed, despite a slightly increased amount of precipitation. Perhaps it was due to the fact that the extremely high summer temperatures were recorded in 2014, the temperature maximum of July was fixed. In 2015, the average daily temperatures were close to normal, the amount of precipitation exceeds the norm, and the maximum pollen productivity of plants is observed for the three years studied.

\section{Conclusions}

The performed research has shown that there was a big amount of pollen of non-local vegetation in the spore-pollen spectra. Of the 39 taxonomic groups of plants found in the spore-pollen spectra of the Tauber trap № 1, only 13 had the representatives among the local vegetation. The remaining 26 taxonomic groups reflect the nature of the neighboring phytocenoses and the regional vegetation. Of the 49 taxonomic groups of plants found in the samples from the trap № 2, 17 taxa had the representatives among the local vegetation, 32 showed the sublocal and regional vegetation.

Betula pendula pollen predominates in the all analyzed spectra. The spore-pollen spectra in the samples of the Tauber trap № 2 contains more species than the spectra of the trap № 1. It may be due to the proximity to the gardening areas, since there were a lot of pollen of the representatives of weed plants in the spectra.

There is a link between the generative productivity of plants and weather conditions of the year. Pollen productivity increases with elevated temperatures and high precipitation in the winter season. In the summer, the pollen productivity of tree species decreases at temperatures above normal and small amounts of precipitation.

\section{References}

Frenguelli G., Spieksma F. Th. M., Bricchi E., Romano B., Mincigrucci G., Nikkels A. H., Dankaart W. \& Ferranti E., 1991, The influence of air temperature on the starting dates of the pollen season of Alnus and Populus, Grana 30: 196-200.

Furnessa C.A., 1994, The extraction and identification of pollen from a beeswax statue. - Grana 33: 49-52.

Google Maps [Electronic resource], 2005-2017, Cartographic service, Mountain-View. - URL: https://www. google.ru/maps (date: 02.06.2016).

Stockmarr J., 1971, Tablets with spores used in absolute pollen analysis, Pollen et Spores 13: 615-621.

Tauber H., 1974, A static non-overload pollen collector, New Phytologist 73: 359-369.

Погода и Климат [Electronic resource]: наиб. полн. мониторинг погоды и климата в глобальн. масштабе, Электрон. дан., 2004-2016. - URL: http:/www. pogodaiklimat.ru (date: 03.06.2016). 